\title{
PENERAPAN MODEL PEMBELAJARAN DISCOVERY LEARNING MENGGUNAKAN MODUL DILENGKAPI PENUGASAN MIND MAPPING UNTUK MENINGKATKAN PRESTASI BELAJAR DAN KREATIVITAS SISWA PADA MATERI KONSEP MOL KELAS X MIPA 3 SEMESTER GENAP DI SMA NEGERI 5 SURAKARTA TAHUN AJARAN 2016/2017
}

\author{
Rahma Ayuningtyas, Endang Susilowati ${ }^{*}$, dan Budi Utami \\ Program Studi Pendidikan Kimia, FKIP, Universitas Sebelas Maret, Surakarta, Indonesia \\ Keperluan korespodensi, telp : 081548553791, email: endwati@yahoo.com
}

\begin{abstract}
ABSTRAK
Penelitian ini bertujuan untuk meningkatkan prestasi belajar dan kreativitas siswa kelas $\mathrm{X}$ MIPA 3 SMA Negeri 5 Surakarta Tahun Pelajaran 2016/2017 dengan penerapan model pembelajaran discovery learning menggunakan modul dilengkapi mind mapping pada materi konsep mol. Penelitian ini merupakan Penelitian Tindakan Kelas (PTK) yang dilaksanakan dalam dua siklus. Setiap siklusnya terdapat empat tahapan yang terdiri dari perencanaan tindakan, pelaksanaan tindakan, observasi, dan refleksi. Subjek penelitian adalah siswa kelas X MIPA 3 SMA Negeri 5 Surakarta Tahun Pelajaran 2016/2017. Teknik pengumpulan data melalui observasi, wawancara, kajian dokumen, angket dan tes. Teknik analisis yang digunakan dalam penelitian ini adalah deskriptif kualitatif. Berdasarkan hasil penelitian dapat disimpulkan bahwa penerapan model pembelajaran discovery learning dapat meningkatkan prestasi belajar dan kreativitas siswa pada materi konsep mol kelas X MIPA 3 SMA Negeri 5 Surakarta tahun pelajaran 2016/2017. Pada siklus I persentase ketercapaian prestasi belajar aspek pengetahuan, aspek sikap, aspek keterampilan, dan kreativitas masing-masing adalah 34\%; 100\%; $100 \%$ dan $47 \%$. Pada siklus II, masing-masing persentase ketercapaian prestasi belajar aspek pengetahuan dan kreativitas meningkat menjadi $66 \%$ dan $78 \%$.
\end{abstract}

Kata kunci : discovery learning, modul, mind mapping, prestasi belajar, kreativitas, konsep mol

\section{PENDAHULUAN}

Pendidikan di Indonesia merupakan bidang yang masih memerlukan perbaikan dan perhatian dari pemerintah. Berbagai upaya secara terus menerus telah dilakukan pemerintah untuk meningkatkan mutu pendidikan di Indonesia melalui berbagai program dan kegiatan. Salah satu upaya yang dilakukan oleh pemerintah untuk memperbaiki mutu pendidikan adalah dengan penyempurnaan kurikulum pendidikan. Pendidikan tingkat dasar dan menengah di Indonesia telah mengalami beberapa pembaharuan kurikulum, sampai saat ini Indonesia telah mengalami sebelas kali pembaharuan kurikulum [1].
Kurikulum 2013 adalah kurikulum yang berbasis pada karakter dan kompetensi sikap, keterampilan, dan pengetahuan [1]. Dengan pendekatan tematik integratif dan contextual teaching learning (CTL) kurikulum 2013 ingin mengubah pola pendidikan dari yang berorientasi terhadap hasil dan materi menjadi pendidikan sebagai proses. Untuk mencapai hal tersebut di atas, pembelajaran harus sebanyak mungkin melibatkan peserta didik, supaya mereka mampu bereksplorasi dalam mencapai kompetensi dengan cara menggali berbagai potensi dan kebenaran secara ilmiah [2]. Dalam hal inilah perlunya kreativitas guru, agar mereka mapu menjadi fasilitator dan mitra belajar bagi peserta didik. Guru dituntut untuk kreatif 
memberikan layanan dan kemudahan belajar (facilitate learning) kepada peserta didik, supaya mereka dapat belajar dalam suasana menyenangkan, gembira, penuh semangat, tidak cemas, dan berani mengungkapkan pendapat secara terbuka agar peserta didik dapat memenuhi kompetensi sikap, pengetahuan dan ketrampilan secara seimbang.

SMA Negeri 5 Surakarta saat ini menggunakan kurikulum 2013. Namun setelah observasi lebih lanjut ternyata kondisi di lapangan banyak yang tidak sesuai dengan Kurikulum 2013. Salah satu permasalahannya adalah masih banyak guru yang masih mengacu pada pembelajaran berpusat pada guru (teacher centered learning). Dengan sistem pembelajaran berpusat pada guru, akibatnya peserta didik menjadi kurang kreatif dalam mengatasi masalah sehingga pada akhirnya hasil belajar menjadi rendah serta kompetensi sikap dan keterampilan tidak dapat terpenuhi.

Berdasarkan hasil observasi, siswa-siswi kelas X MIPA 3 SMA Negeri 5 Surakarta Tahun Pelajaran 2016/2017 kreativitasnya tergolong masih rendah. Hal ini nampak ketika siswa mengerjakan soal, mereka hanya bisa mengerjakan soal dengan tingkat kesukaran rendah dan jenis soal sederhana yang sudah dicontohkan oleh guru. Sedangkan soal yang lebih variatif dan dengan kesukaran lebih tinggi siswa kesulitan untuk menemukan cara untuk mengerjakan soal tersebut. Siswa hanya terpaku dengan cara yang sudah dicontohkan oleh guru, belum dapat berpikir kreatif untuk menemukan cara lain untuk mengerjakan suatu soal. Sehingga siswa akan kesulitan dalam materi-materi yang mencakup pemahaman konsep dan membutuhkan ide-ide baru untuk memecahkan suatu persoalan, seperti soal-soal hitungan dalam materi konsep mol. Oleh karena itu kreativitas siswa sangat berpengaruh terhadap prestasi belajar siswa pada materi konsep mol.

Konsep mol termasuk submateri dari materi stoikiometri, materi ini diajarkan pada kelas $X$ semester genap. Konsep mol merupakan salah satu dasar dari perhitungan kimia (stoikiometri). Perlunya pemahaman konsep, mema- hami rumus dan kemampuan berpikir kreatif tinggi untuk dapat menguasai materi konsep mol, sebab siswa harus menghubungkan konsep dasar yang telah diperoleh sebelumnya dan mengaplikasikannya dalam konsep perhitungan kimia [3].

Berdasarkan hasil wawancara dengan guru dan observasi dalam kelas di SMA Negeri 5 Surakarta, karakteristik siswa kelas X MIPA 3 merupakan siswa yang kurang kreatif. Sesuai kurikulum yang berlaku kreativitas siswa sangat dituntut dalam pembelajaran, sehingga guru harus lebih banyak membantu siswa untuk lebih kreatif, maka jika guru melakukan pembelajaran yang kreatif maka siswa akan ikut kreatif, begitu pula sebaliknya. Siswa tentu akan senang guru menggunakan model pembelajaran yang baru namun apabila materi yang akan disampaikan tidak dapat tercapai dengan baik, akan menjadi suatu masalah. Sehingga diperlukan model pembelajaran yang sesuai dan efisien agar siswa dapat aktif dalam pembelajaran dan kreativitas siswa dapat berkembang sehingga siswa dapat memecahkan berbagai persoalan.

Berbagai permasalahan di atas dapat diatasi salah satunya dengan cara Penelitian Tindakan Kelas (PTK). Penelitian Tindakan Kelas adalah suatu bentuk penelitian yang memungkinkan para guru mempelajari ruang kelas mereka sendiri-misalnya, metode instruksional mereka sendiri, dan juga aiswa dan penilaian mereka sendiri-agar mendapat pemahaman yang lebih baik dan lebih mampu meningkatkan kualitas atau efektivitas mereka. Secara spesifik Penelitian Tindakan Kelas berfokus pada karakteristik dari populasi, berdasarkan inilah beberapa tindakan yang sesuai akan dijalankan [4]. Dengan dilakukannya Penelitian Tindakan Kelas (PTK) menggunakan model dan media pembelajaran yang disesuaikan dengan materi yang akan disampaikan, karakteristik siswa, sarana pembelajaran yang tersedia, serta tujuan pembelajarannya, diharapkan mampu meningkatkan prestasi belajar siswa.

Salah satu model pembelajaran yang dapat digunakan adalah discovery 
learning untuk dapat mewujudkan pembelajaran yang memberikan ruang yang cukup untuk siswa berkreativitas, serta menitik beratkan pada pembentukan konsep yang didukung oleh lingkungan belajar interaktif, inovatif dan memberi kesempatan siswa untuk berpartisipasi aktif. Discovery learning merupakan salah satu model pembelajaran yang menekankan pada pembentukan konsep oleh siswa secara mandiri [5].

Menurut Munandar [6] bahwa mengajar dengan discovery selain berkaitan dengan penemuan juga bisa meningkatkan kemampuan berpikir kreatif. Dalam pembelajaran discovery menuntut siswa untuk menemukan hal baru, Proses untuk menemukan hal baru diperlukan kreativitas, sehingga dengan model discovery learning dan sintak yang ada di dalamnya yaitu stimulasi, identifikasi masalah, pengumpulan data, pengolahan data, verifikasi, dan generalisasi dapat meningkatkan kreativitas siswa, hal ini sesuai dengan hasil penelitian yang dilakukan sebelumnya bahwa rata-rata kemampuan berpikir kreatif kelas yang mendapatkan pembelajaran dengan model discovery learning berpendekatan saintifik bermuatan karakter lebih baik dari pada rata-rata kelas yang mendapatkan pembelajaran ekspositori [7].

Namun berdasarkan kenyataan di lapangan guru masih mengalami kesulitan menerapkan model discovery learning. Masalah ini diantaranya disebabkan karena belum tersedianya bahan ajar yang dapat membimbing dan menuntun siswa untuk menemukan konsep atau pengetahuan baru sesuai prinsip model discovery learning. Model discovery learning menuntut proses pembelajaran berpindah dari situasi teacher centered learning ke situasi student centered learning, sedangkan guru berperan sebagai mediator dan fasilitator. Oleh karena itu guru dituntut untuk menyiapkan bahan ajar yang dapat menuntun siswa belajar mandiri, seperti modul [8].

Mind mapping (peta pikiran) merupakan suatu metode pembelajaran yang sangat baik digunakan oleh guru untuk meningkatkan daya hafal siswa dan pemahaman konsep siswa yang kuat, siswa juga dapat meningkatkan daya kreativitas melalui kebebasan berimajinasi. Lebih lanjut dijelaskan bahwa mind mapping (peta pikiran) adalah eksplorasi kreatif yang dilakukan oleh individu tentang suatu konsep secara keseluruhan, dengan membentangkan subtopik-subtopik dan gagasan yang berkaitan dengan konsep tersebut dalam satu presentasi utuh pada selembar kertas, melalui penggambaran simbol, kata-kata, garis, dan tanda panah [9].

Modul dilengkapi mind mapping merupakan modul yang berisikan materi dan latihan tentang konsep mol dimana langkah-langkah pembelajaran dari modul akan menuntun siswa untuk dapat membuat mind mapping yang membantu siswa untuk pembelajaran di kelas maupun untuk belajar mandiri. Modul dilengkapi mind mapping ini diharapkan dapat meningkatkan kreativitas dan membimbing siswa untuk menemukan konsep baru. Kombinasi yang cocok dalam penggunaan model pembelajaran discovery learning ditunjang dengan penggunaan media belajar berupa Modul dilengkapi mind mapping diharapkan dapat meningkatkan kreativitas siswa dalam berpikir sehingga prestasi belajar siswa dapat meningkat.

\section{METODE PENELITIAN}

Penelitian ini merupakan Penelitian Tindakan Kelas (PTK) yang dilaksanakan dalam dua siklus. Setiap siklusnya terdapat empat tahapan, yaitu perencanaan, pelaksanaan, observasi, dan refleksi. Subjek penelitian adalah siswa kelas X MIPA 3 SMA Negeri 5 Surakarta tahun pelajaran 2016/2017. Pemilihan subjek dalam penelitian ini didasarkan pada hasil observasi yang dilakukan pada saat prasiklus, dimana subjek yang dipilih tersebut teridentifikasi mempunyai permasalahan dalam pembelajaran yaitu prestasi belajar dan kreativitas yang rendah.

Sumber data adalah guru dan siswa. Analisis data dalam penelitian ini dilakukan dari awal sampai berakhirnya 
pengumpulan data. Data yang didapat dari hasil penelitian diolah dan dianalisis secara deskriptif kualitatif. Teknik analisis kualitatif mengacu pada model analisis Miles dan Huberman [10] melalui proses reduksi data, penyajian data, penarikan kesimpulan dan verifikasi. Pada penelitian ini digunakan teknik triangulasi agar didapatkan data yang valid dan menggambar kondisi siswa sesungguhnya. Triangulasi merupakan teknik pemeriksaan keabsahan data yang memanfaatkan sesuatu yang lain di luar data untuk keperluan pengecekan atau sebagai pembanding terhadap data itu. Teknik triangulasi yang digunakan adalah teknik triangulasi metode yang dilakukan dalam mengumpulkan data tetap dari sumber data yang berbedabeda. Dalam penelitian ini menggunakan metode pengumpulan data melalui observasi, angket, tes dan wawancara.

\section{HASIL DAN PEMBAHASAN}

\section{Siklus I}

Pada tahap perencanaan siklus I dilakukan penyusunan silabus, RPP, media pembelajaran, instrumen prestasi belajar, serta instrumen penilaian kreativitas. Berdasarkan silabus peneliti menyusun RPP untuk empat pertemuan pada proses pembelajaran siklus I.

Kegiatan pembelajaran yang telah direncanakan didesain menggunakan model pembelajaran discovery learning. Perincian pembelajaran pada siklus I yaitu 6 JP $\left(\begin{array}{lllll}6 & x & 45 & \text { menit }) & \text { untuk }\end{array}\right.$ penyampaian materi dan $3 \mathrm{JP}(3 \times 45$ menit) untuk evaluasi siklus I.

Pengamatan terhadap siswa dilakukan selama proses pembelajaran berlangsung. Pada awal pembelajaran, siswa masih belum terbiasa dengan model discovery learning. Hal ini dapat diketahui ketika siswa merasa bingung mengapa mereka harus melakukan identifikasi masalah, membuat hipotesis dan mengumpulkan data untuk dapat memperoleh kesimpulan dari pembelajaran, serta tugas untuk membuat mind mapping. Sehingga guru harus menjelaskan kembali tujuan dari digunakannya model pembelajaran tersebut.
Pada pertemuan selanjutnya siswa mulai terbiasa dengan metode discovery learning. Dalam kegiatan diskusi siswa sudah mulai aktif dan berkerjasama untuk memecahkan permasalahan dengan diskusi. Siswa semakin antusias mengerjakan lembar kegiatan pada modul, mempresentasikan hasil diskusi serta mengerjakan tugas mind mapping dan posttest. Beberapa siswa juga tidak sungkan untuk bertanya kepada siswa yang sedang presentasi di depan kelas dan bertanya kepada guru ketika ada materi yang belum jelas saat pembelajaran.

Penilaian tindakan pada siklus I meliputi penilaian aspek pengetahuan, sikap, keteampilan, dan kreativitas. Hasil penilaian tindakan pada siklus I dapat dilihat pada Tabel 1.

Tabel 1. Hasil Tindakan Siklus I

\begin{tabular}{lcc}
\hline $\begin{array}{c}\text { Aspek yang } \\
\text { dinilai }\end{array}$ & $\begin{array}{c}\text { Ketercapaian } \\
(\%)\end{array}$ & Ket $^{*}$ \\
\hline Pengetahuan & 34 & BT \\
Sikap & 100 & T \\
Keterampilan & 100 & T \\
Kreativitas & 47 & BT \\
\hline *Keterangan : T (Tercapai), BT (Belum Tercapai)
\end{tabular}

Berdasarkan Tabel 1 dapat diketahui bahwa Indikator yang belum mencapai target adalah kompetensi pengetahuan dan kreativitas. Pada kompetensi pengetahuan ketercapaian sebesar 34\%. Berdasarkan ketercapaian tiap indikator kompetensi masih ada tiga indikator yang belum mencapai target yaitu indikator menentukan massa atom relatif $(\mathrm{Ar})$ dan massa molekul relatif (Mr), menentukan volume suatu gas, dan Mengkonversi jumlah mol dengan jumlah partikel, massa, dan volume zat, Rendahnya ketuntasan aspek pengetahuan dikarenakan siswa masih kebingungan dalam penggunaan rumus konsep mol, kesulitan perkalian dan pembagian bilangan desimal, serta kurangnya keseriusan siswa dalam mengerjakan soal ujian.

Untuk aspek kreativitas ketercapaiannya sebesar $47 \%$. Untuk hasil penilaian kompetensi sikap dan 
keterampilan sudah mencapai target yang ditentukan. Ketercapaian kompetensi sikap dan keterampilan masingmasing mencapai $100 \%$. Pada siklus II tidak dilakukan penilaian sikap dan keterampilan lagi karena semua aspek sikap dan keterampilan sudah tercapai.

Berdasarkan hasil yang diperoleh pada siklus I dimana kompetensi pengetahuan dan kreativitas belum mencapai target ketercapaian, maka perlu dilakukan tindakan lebih lanjut dengan melakukan pembelajaran pada siklus II. Pembelajaran pada siklus II ini dilakukan untuk memperbaiki proses pembelajaran pada siklus I sehingga diharapkan semua indikator kompetensi dapat mencapai target ketuntasan.

\section{Siklus II}

Pada pelaksanaan siklus II ini lebih difokuskan untuk perbaikan terhadap kendala-kendala yang muncul pada siklus I. Instrumen pembelajaran yang digunakan dalam siklus II adalah RPP dan instrumen penilaian meliputi tes objektif, angket dan lembar observasi. Instrumen penilaian yang disusun oleh peneliti pada siklus II hanya soal tes objektif untuk kompetensi pengetahuan dan tes kreativitas saja.

Kegiatan pembelajaran yang telah direncanakan didesain menggunakan model pembelajaran discovery learning. Perincian pembelajaran pada siklus II yaitu 3 JP (3 $\times 45$ menit) untuk penyampaian materi dan 3 JP $(3 \times 45$ menit) untuk evaluasi siklus II.

Pada proses pembelajaran guru menekankan konsep-konsep pokok yang belum dipahami siswa dari hasil analisis refleksi pada tindakan siklus I. Materi yang diberikan juga fokus pada indikatorindikator yang belum mencapai ketuntasan yaitu menentukan massa atom relatif $(\mathrm{Ar})$ dan massa molekul relatif $(\mathrm{Mr})$, menentukan volume suatu gas, dan mengkonversi jumlah mol dengan jumlah partikel, massa, dan volume zat. Pemberian evaluasi juga terbatas pada soal dengan indikatorindikator yang belum tuntas saja.
Kelompok diskusi pada siklus II ini dibuat lebih sedikit anggotanya. Hal ini dilakukan supaya diskusi lebih efektif sehingga siswa lebih paham materi yang didiskusikan dan siswa yang belum tuntas dapat tuntas pada evaluasi siklus II.

Penilaian tindakan siklus II meliputi penilaian aspek pengetahuan dan kreativitas. Hasil penilaian tindakan selama tindakan siklus II disajikan dalam Tabel 2.

Tabel 2. Hasil Tindakan Siklus II

\begin{tabular}{lcc}
\hline $\begin{array}{c}\text { Aspek yang } \\
\text { dinilai }\end{array}$ & $\begin{array}{c}\text { Ketercapaian } \\
(\%)\end{array}$ & Ket* $^{\star}$ \\
\hline Pengetahuan & 66 & $\mathrm{~T}$ \\
Kreativitas & 78 & $\mathrm{~T}$ \\
\hline
\end{tabular}

${ }^{\star}$ Keterangan : T (Tercapai)

Secara umum, siswa lebih aktif dalam proses pembelajaran siklus II. Siswa lebih bersemangat dalam mengerjakan soal diskusi dari guru. Semua siswa terlibat aktif dalam diskusi kelompok. Siswa juga mulai berinisiatif untuk membaca buku atau literatur lain untuk menjawab soal diskusi. Selain itu siswa juga lebih responsif dalam menjawab pertanyaan yang diajukan oleh guru. Ketika guru meminta siswa menyampaikan pendapat atau menuliskan jawaban soal ke depan kelas siswa sudah mau melakukannya tanpa harus ditunjuk terlebih dahulu.

Berdasarkan hasil pengamatan dan evaluasi yang dilaksanakan pada siklus II bahwa semua aspek telah mencapai target yang telah ditetapkan dan terjadi peningkatan pada setiap aspek.

\section{Perbandingan antar Siklus}

Perbandingan hasil tindakan antar siklus bertujuan untuk mengetahui peningkatan yang terjadi dari siklus I ke siklus II. Berdasarkan hasil penilaian tindakan siklus I dan siklus II diperoleh peningkatan hasil dari semua indikator kinerja yang dinilai. 


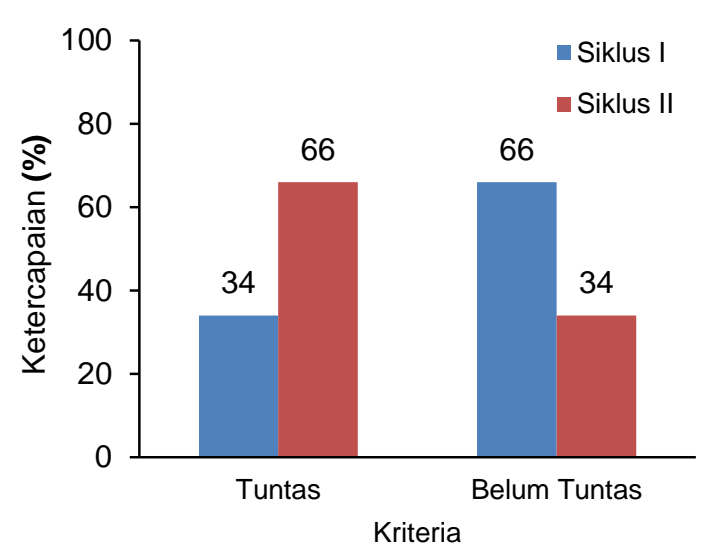

Gambar 1. Peningkatan Ketuntasan Aspek Pengetahuan Siklus I dan II

Berdasarkan Gambar 1, dapat disimpulkan bahwa terdapat peningkatan persentase siswa yang tuntas dari siklus I ke siklus II. Peningkatan ketuntasan pada kompetensi pengetahuan dari siklus I sebesar $34 \%$ menjadi $66 \%$ pada siklus II.

Berikut ini perbandingan capaian aspek pengetahuan tiap indikator kompetensi pada siklus I dan siklus II yang hasilnya dapat dilihat pada Gambar 2.

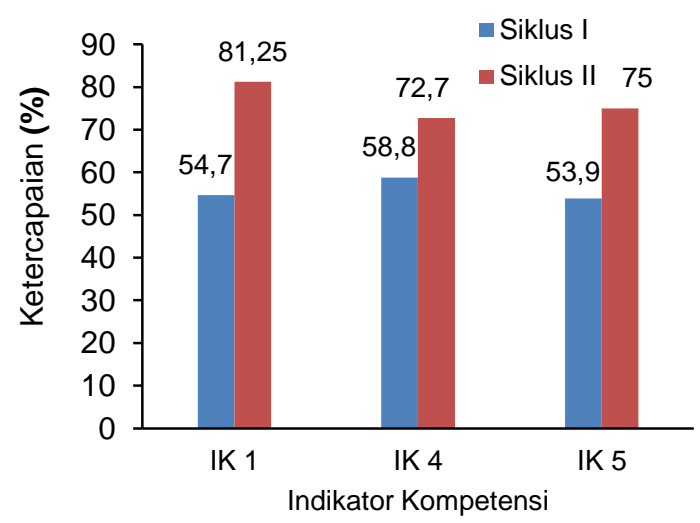

Gambar 2. Peningkatan Capaian aspek pengetahuan masingmasing indikator kompetensi siklus I dan ||

Pada Gambar 2 Indikator Kompetensi 1 menentukan massa atom relatif $(\mathrm{Ar})$ dan massa molekul relatif $(\mathrm{Mr})$, Indikator Kompetensi 4 menentukan volume suatu gas, dan Indikator Kompetensi 5 mengkonversi jumlah mol dengan jumlah partikel, massa, dan volume zat mengalami peningkatan ketuntasan menjadi $81,25 \%$; 72,66\%; dan $75 \%$. Sehingga semua indikator kompetensi yang dipelajari telah tuntas pada siklus II.

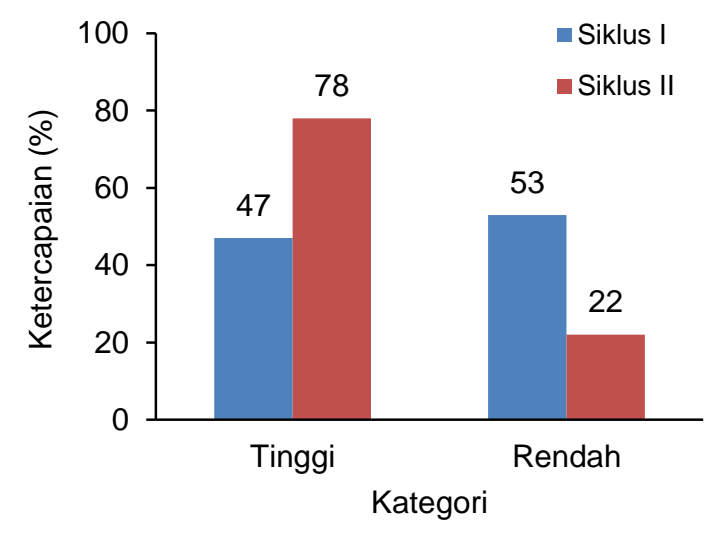

Gambar 3. Peningkatan Ketuntasan Aspek Kreativitas Siklus I dan II

Dari Gambar 3 dapat diketahui bahwa persentase kreativitas siswa dalam kategori tinggi mengalami peningkatan dari siklus I ke siklus II. Peningkatan ini sejalan dengan penurunan pada kategori kreativitas sedang dan rendah. Hal ini menunjukkan bahwa secara umum kreativitas siswa sudah baik dan telah mencapai target ketuntasan dilihat dari peningkatan hasil dari $47 \%$ pada siklus I menjadi $78 \%$ pada siklus II.

Aspek sikap dan keterampilan pada siklus I didapatkan semua siswa telah tuntas. Hal ini membuat aspek sikap dan keterampilan tidak dilaksanakan kembali pada siklus II

Berdasarkan hasil tersebut, penelitian dengan menggunakan model pembelajaran discovery learning menggunakan modul dilengkapi mind mapping dikatakan berhasil karena pada akhir penelitian semua aspek telah mencapai target yang ditetapkan. Penelitian ini dapat meningkatkan proses belajar siswa yaitu kreativitas serta prestasi belajar siswa yang terdiri dari aspek pengetahuan, aspek sikap, dan aspek keterampilan.

Keberhasilan atas model pembelajaran discovery learning juga diungkapkan oleh Puspitadewi [11], bahwa penggunaan model pembelajaran discovery learning dalam pembelajaran kimia dapat meningkatkan prestasi belajar siswa. Selain itu, penelitian Vahlia 
[12] tentang pembelajaran discovery learning dapat meningkatkan prestrasi belajar dan kreativitas siswa.

\section{KESIMPULAN}

Berdasarkan hasil penelitian yang telah dilakukan, maka dapat disimpulkan bahwa penerapan model pembelajaran discovery learning menggunakan modul dilengkapi mind mapping dapat meningkatkan prestasi belajar dan kreativitas siswa pada materi konsep mol kelas X MIPA 3 SMA N 5 Surakarta tahun ajaran 2016/2017.

\section{UCAPAN TERIMA KASIH}

Penelitian ini dapat terselenggara dengan baik karena bantuan dari berbagai pihak. Oleh karena itu penulis ingin mengucapkan terima kasih kepada Kepala SMA Negeri 5 Surakarta, Bapak Drs. Yusmar Setyobudi, MM., M.Pd., atas izin yang diberikan kepada penulis untuk melakukan penelitian, dan kepada guru kimia kelas X MIPA 3 Bapak Drs. F. Srihartono yang telah memberikan bantuan dan arahan selama penelitian.

\section{DAFTAR RUJUKAN}

[1] Kurniasih, I., \& Sani, B. (2014). Sukses mengimplementasikan kurikulum 2013. Jakarta: Kata Pena.

[2] Mulyasa. (2013). Pengembangan dan Implementasi Kurikulum 2013. Bandung: PT Remaja Rosdakarya

[3] Yanti, D.F., Afandy, D., \& Su'aidy, M. (2013). Identifikasi Pemahaman Materi Perhitungan Kimia (Stoikiometri) pada Siswa Kelas $X$ SMA Negeri 10 Malang Semester II Tahun Ajaran 2012/2013. Jurnal Pendidikan Kimia Universitas Malang . 2 (1), 1-6

[4] Metler, C.A. (2014). Action Research: Improving Schools and Empowering Educators. California: Sage Publications, Inc.

[5] Wenning, C.J. (2011). The Levels of Inquiry Model Of Science Teaching. Journal of Physics Teacher Education Online. 6 (2), 9-16
[6] Munandar, U. (1999). Kreativitas dan Keberbakatan Strategi Mewujudkan Potensi Kreatif dan Bakat. Jakarta: Gramedia

[7] Rudyanto, H.E. (2014). Model Discovery Learning dengan Pendekatan Saintifik Bermuatan Karakter untuk Meningkatkan Kemampuan Berpikir Kreatif. Premiere Educandum. 4 (1), 41-48

[8] Udo, M E. (2010). Effect of GuidedDiscovery, Student-Centred Demonstration and the Expository Instructional Strategies on Students Performance in Chemistry. An International Multi Disciplinary Journal, Ethiopia. 4 (4), 389-398

[9] Sugiarto, I. (2004). Mengoptimal-kan Daya Kerja Otak dengan Berpikir Holistic dan Kreatif. Jakarta: Gramedia Pustaka Utama

[10] Sugiyono. (2008). Metode Penelitian Pendidikan: Pendekatan Kuantitatif, Kualitatif dan $R$ \& $D$. Bandung: Alfabeta.

[11] Puspitadewi, R., Agung, N.C.S, \& Ashadi. (2016). Penerapan Model Pembelajaran Discovery Learning Untuk Meningkatkan Minat dan Prestasi Belajar Siswa Pada Materi Kelarutan dan Hasil Kali Kelarutan Kelas XI MIA 3 Semester Genap SMA N 1 Teras Tahun Pelajaran 2015/2016. Jurnal Pendidikan Kimia (JPK). 5 (4), 114-119

[12] Vahlia, Ira. (2014) Eksperimentasi Model Pembelajaran Discovery Learning dan Group Investigation Terhadap Prestasi Belajar Matematika ditinjau Dari Kreativitas Siswa. Jurnal Pendidikan Matematika FKIP Univ. Muhammadiyah Metro. 3 (2), 43-54 